of Manitoba, and remained in Winnipeg until 1920. $\mathrm{He}$ had to create an entirely new department there, a task which he performed so successfully that when he left Winnipeg to return to London as professor of physiology at the Middlesex Hospital, the University of Manitoba paid him a well-deserved tribute by conferring upon him an honorary LL.D. In London it again fell to his lot to reorganise the Department of Physiology, and its active scientific state when he retired in 1930 bears witness to the success of his efforts. Swale Vincent was at various times examiner in the University of London and the University of Leeds, and also of the Conjoint Board. $\mathrm{He}$ had been secretary of the Ductless Glands Committee of the British Association since 1898. In Canada he served as a member of the Industrial Fatigue Board.

Swale Vincent's numerous publications cover a large part of endocrinology. Beginning with a study of the suprarenal glands, he proceeded to investigations on the pituitary, the thymus, the thyroid and parathyroid glands, and the Islets of Langerhans. He was a prominent representative of the Schafer school of physiology which, regarding the cell as a basic unit of physiological functions, combines histological studies with experimental technique. The present generation of physiologists who can buy most of the various internal secretions in a more or less pure state at a chemist's shop, must find it difficult to realise the laborious investigations required to understand the morphological and functional relationships of the different parts of the endocrine organs, most of which are formed as a result of the joining up of histogenetically and functionally different tissues.

In extending his investigations to the action of normal tissues other than endocrine organs, Swale Vincent discovered the existence of substances present in all tissues producing a marked lowering of blood pressure and different from choline. One of these substances was identified later by Barger and Dale as histamine, the subsequent study of which in the hands of Dale and his collaborators has revealed its profound physiological significance. Swale Vincent was a careful worker, with a highly critical mind, qualities which enabled him to make positive contributions of lasting value, and to clear the new science of endocrinology from many pseudo-scientific weeds. The high international reputation of his work found recognition in the request to write a series of reviews on the ductless glands for Ascher-Spiro's "Ergebnisse der Physiologie". These reviews were later expanded into a book "Internal Secretion and the Ductless Glands" which, first published in 1912 and since passed through three editions, is one of the standard works on the subject. He also published in 1924 an "Introduction to the Study of Secretion" and in 1929 with Prof. Sampson Wright, formerly his pupil and now his successor, "Introduction to Practical Mammalian Physiology".

Swale Vincent was a man of firm principles and high ideals on which he would not compromise. He was essentially a shy man, and this sometimes gave an impression of brusqueness, while to those who had the privilege of knowing him well he was a staunch friend and a charming companion. He had a deep love and a great understanding of music and was himself no mean pianist. It was characteristic that in the last years of his active life he became interested in the study of the physiological reactions of the body to music. In 1914 he married Beatrice, daughter of Mr. W. Overton of London, who survives him, and had two daughters.

W. C.

\section{Dr. KNud Rasmussen}

KNUD Rasmussen, who died in Copenhagen in December last, devoted most of his life to the exploration of Greenland, particularly in regard to the ethnography of the Eskimo. $\mathrm{He}$ was born in Greenland on June 7, 1879, the son of Chr. Rasmussen, who was a pastor in that country and later a lecturer in the University of Copenhagen. His mother was of Eskimo descent.

After taking his degree at Copenhagen, Rasmussen visited Lapland to study the natives and in 1902 returned to Greenland with $M$. Erichsen to examine the social conditions of the Eskimo on the west coast. The report of that two years' study led to several reforms in the Danish system of administration, and in 1905 the Danish Government sent him again to Greenland to explore the conditions for reindeer as a source of livelihood for the natives. From 1906 until 1909 he was in Greenland studying Eskimo folk-lore, and his visits to the isolated Polar Eskimo of the Cape Yuk area led to the foundation in 1909 of the mission station of Nordstjernen in North Star Bay. The following year Rasmussen added a trading station and changed the name to Thule. Afterwards the mission station was moved farther north, and Thule became the base for a long series of scientific expeditions under Rasmussen, in most of which he successfully used the Eskimo technique in travelling and hunting.

The first Thule expedition, in 1912, crossed the ice-sheet in the north-west to Danmark Fjord and Independence Fjord, thus linking the discoveries of Peary with those of Erichsen. After spending some time in exploring around Thule and Melville Bay, Rasmussen led the second Thule expedition in 1916-18 to explore the topography and structure of the north-west coast. The return to Thule over the edge of the ice-sheet led to the death of the Swedish botanist, Th. Wulff, who succumbed to the hardships. This expedition convinced Rasmussen that there can have been no migration of Eskimo round the north to the east coast of Greenland. Rasmussen did not take part in the third Thule expedition but devoted the fourth, in 1919, to a study of the folk-lore of the east coast Eskimo. The fifth Thule expedition, in 1921-24, entailed a journey, with K. BirketSmith, from Greenland to Bering Strait through the whole extent of Eskimo territory with the view of studying the origin and evolution of 
Eskimo culture. He found the oldest culture among the Caribou Eskimo, west of Hudson Bay. This spread to the arctic coasts and became dependent on marine animals, and then east and west until the Thule culture was homogeneous from Greenland to Alaska. An Alaskan culture, borrowing Asiatic influences, spread eastward as far as Greenland and is superimposed on the earlier culture. Rasmussen's researches on the Caribou Eskimo were a new chapter in ethnography.

With Denmark's increased attention to East Greenland subsequent to her suzerainty being established over the whole country, Rasmussen turned his attention to the east in the sixth Thule expedition of 1931. The aim was to explore the coast between Cape Farewell and Angmagssalik. Many additions to the charts were made and it was found that this part of the east coast is relatively free from ice in late summer. The seventh Thule expedition of 1932 was the largest that Rasmussen led. It was also the first on which he made aerial surveys. The work was the outcome of the previous year's reconnaissance and resulted in detailed surveys from Cape Farewell to Umivik, as well as two flights across the ice-sheet. Equally important was the archæological work on former Eskimo habitation of the coast. Rasmussen decided that seals were numerous enough to support a scattered Eskimo community. Hunters remained to investigate this problem more fully.
It was from a resumption of this work that

Rasmussen returned ill to Copenhagen last year.

Several of Rasmussen's works have been translated into English, including "The People of the Polar North" (1908), "Greenland by the Polar Sea" (1921) and "Across Arctic America" (1927). The reports of the various expeditions appeared in English and Danish in Meddelelser om Grönland and elsewhere. He also wrote several books in Danish including "Nye Mennesker" (1905), "Under Nordenvindens Svöbe" (1906) and "Myter og Sagn fra Grönland" (1921-25). In all his works he had the happy faculty of combining a charming lucidity of style with a wealth of information. Among the many honours bestowed on Rasmussen were the Founder's Medal of the Royal Geographical Society, the Danish Medal of Merit and the orders of Dannebrog, St. Olav and the North Star.

R. N. R. B.

\section{We regret to announce the following deaths:}

Sir William Hardy, F.R.S., director of food investigation in the Department of Scientific and Industrial Research, secretary of the Royal Society in 1915-25, and president this year of the British Association, on January 23, aged sixty-nine years.

Dr. F. L. Kitchin, F.R.S., palæontologist to H.M. Geological Survey of Great Britain, on January 20, aged sixty-three years.

\section{News and Views}

\section{The Endless Adventure of Government}

Problems of government and citizenship in the modern world were discussed by Mr. Walter Elliot, the Minister of Agriculture, in his rectorial address as Rector of the University of Aberdeen on January 18. Government to-day, he said, is passing through a great transformation both at home and abroad. Governments and States are no longer merely geographical or political units, but economic units which every kind of intercourse has to take into consideration. Production is becoming decentralised ; international trade less and less an interchange of specialised lines of production and more and more a com. petition in similar lines. The powers of modern science tend to make it feasible for specialised lines to be produced anywhere in the world, or to be replaced by others just as good; hence the national unit has become possible, although not necessarily desirable.

\section{Interdependence of Various Countries}

THE formula of the continually increasing interdependence of the world requires qualification. $\mathrm{Mr}$. Elliot gave three examples in illustration. In the first he traced the change in the economic aspect of the trade in nitrate for use as a fertiliser. In the nineteenth century a great trade was built up with South America; steel rails went out and nitrate came back. Large fortunes were made, international lending improved, and the economists were happy.
But men of science, thinking it unnecessary to transport nitrogen to fields already supporting the pressure of a column composed mainly of that gas, found a means of producing it in Europe, which was good for production but bad for trade. Referring to the neon lamp, Mr. Elliot said it was the old lamp, and not the new, which demanded all the paraphernalia of nineteenth century economics; whilst the new artificial plastics derived from acetylene are replacing walnut and maple and the mahogany which took our forefathers to the West Indies. Mr. Elliot next turned to foreign investment, another section of the world's work where interdependence is no such certain sequence as was once assumed. A great deal of what is described as 'trade' is not exchange, but investment. The uneconomic nature of a great deal of foreign development has been masked by the free gift to competitors of transport systems, railway and steamer lines, which have been constructed at the expense of the producers in Great Britain and presented to their competitors.

\section{Marketing Boards}

THE 'endless adventure of government, has become the problem of problems, the real riddle of the Sphinx. The reason is immediate fear-fear both of war and of peace. Organisation is essential ; there are two methods-to organise the world at once, or to organise smaller units and gear them up to each other as soon as time and hard thinking will 